\section{Funding forgotten proteins}

\section{By Chris Cain, Associate Editor}

A new NIH program is highlighting understudied members of druggable protein classes including GPCRs, kinases, nuclear receptors and ion channels. The goal is to support exploratory projects that might otherwise go unfunded because of a lack of preliminary data.

Since the completion of the human genome project, it has become increasingly clear that the vast majority of NIH-funded research is focused on a relatively small subset of proteins, even among protein classes considered druggable. For example, the Structural Genomics Consortium published an analysis that showed that as of September 2012 only 9 of the 512 kinases in the human genome were the primary target of approved small molecule or biologic drugs. ${ }^{1}$

\section{"The peer-review process often lacks enthusiasm for basic discovery projects when reviewers would prefer to see more preliminary data, but researchers need more money to get that data." \\ -Ronald Margolis, \\ National Institute of Diabetes and Digestive and Kidney Diseases}

Last month, the NIH launched the Illuminating the Druggable Genome (IDG) program and awarded $\$ 5.8$ million from its Common Fund for a pilot phase that includes 9 projects (see Table 1, "Druggable projects"). Seven will use unbiased approaches to study members of the selected protein families, while two will help build a database to publicly distribute the data.

The IDG call for proposals went out last September and sought cium- to high-throughput technology approaches to study druggable protein families. IDG coordinator Ronald another project is computational."

Margolis is a program director within the Division of Diabetes, Endocrinology and Metabolic Diseases at the NIH's National Institute of Diabetes and Digestive and Kidney Diseases.

In addition to the screening projects, a separate call went out to develop a knowledge center that could distribute the data generated. "The goal is to coalesce information from many different projects and put it in one place, with a searchable web portal and informatics tools that can be used to pull out information," Margolis said.

According to Margolis, the initiative aims to break the mold and support projects with little preliminary data. "The peer-review process often lacks enthusiasm for basic discovery projects when reviewers would prefer to see more

Table 1. Druggable projects. The NIH has allocated $\$ 5.8$ million to fund 7 research projects that explore the biology of GPCRs, ion channels, kinases and nuclear receptors, as well as a data-management center.

Source: NIH

\begin{tabular}{|c|c|c|c|}
\hline $\begin{array}{l}\text { Principal } \\
\text { investigator }\end{array}$ & Institution & Project title & Project summary \\
\hline Steven Finkbeiner & Gladstone Institutes & $\begin{array}{l}\text { Physical exam of human neurons to } \\
\text { identify functions of the druggable } \\
\text { genome }\end{array}$ & $\begin{array}{l}\text { Automated live-cell imaging with fluorescent } \\
\text { biosensors to study GPCR and nuclear hormone } \\
\text { receptor function }\end{array}$ \\
\hline Gary Johnson & $\begin{array}{l}\text { The University of North Carolina at } \\
\text { Chapel Hill School of Medicine }\end{array}$ & $\begin{array}{l}\text { Activation and regulation of } \\
\text { the understudied kinome using } \\
\text { multiplexed inhibitor beads and mass } \\
\text { spectrometry }\end{array}$ & $\begin{array}{l}\text { Kinome analysis using sepharose beads conjugated to } \\
\text { kinase inhibitors for target identification }\end{array}$ \\
\hline Michael McManus & University of California, San Francisco & Unlocking the hidden kinome & $\begin{array}{l}\text { Epistatic analysis including generating double } \\
\text { knockouts of combinations of all } 518 \text { human kinases }\end{array}$ \\
\hline Jun Qin & Baylor College of Medicine & $\begin{array}{l}\text { Signaling networks of nuclear receptor } \\
\text { transcriptional cross-talk in lung cancer }\end{array}$ & $\begin{array}{l}\text { Use of transcription factor response element pulldown } \\
\text { to profile nuclear receptor dynamics and cross-talk in } \\
\text { response to stimuli }\end{array}$ \\
\hline $\begin{array}{l}\text { Bryan Roth and } \\
\text { Brian Shoichet }\end{array}$ & $\begin{array}{l}\text { The University of North Carolina at } \\
\text { Chapel Hill School of Medicine }\end{array}$ & $\begin{array}{l}\text { Scalable technologies for illuminating } \\
\text { the druggable GPCR-ome }\end{array}$ & $\begin{array}{l}\text { Screening of 5,321 drugs and reagents as well as } \\
\text { additional computational screens to identify ligands } \\
\text { for orphan GPCRs }\end{array}$ \\
\hline Susumu Tomita & Yale School of Medicine & $\begin{array}{l}\text { Identify functional modulators of } \\
\text { ionotropic neurotransmitter receptors } \\
\text { in the brain }\end{array}$ & $\begin{array}{l}\text { High throughput screening using transmembrane open } \\
\text { reading frame collections to identify modulators of } \\
\text { cationic ionotropic neurotransmitter receptors }\end{array}$ \\
\hline $\begin{array}{l}\text { Joanna Yeh and } \\
\text { David Kokel }\end{array}$ & Massachusetts General Hospital & $\begin{array}{l}\text { Scalable in vivo tools for annotating and } \\
\text { manipulating the druggable genome }\end{array}$ & $\begin{array}{l}\text { Screening in zebrafish for druggable targets involved in } \\
\text { CNS function }\end{array}$ \\
\hline
\end{tabular}




\section{ANALYSIS}

\section{TRANSLATIONAL NOTES}

preliminary data, but researchers need more money to get that data."

Aled Edwards, director of the Structural Genomics Consortium, agreed that it is a problem that such a high proportion of funded projects are so dependent on old ideas. "As reviewers, we have expectations of what should be included in a grant for it to be funded, so given that all researchers have access to the same literature and there is a formulaic approach to grant writing and funding across different jurisdictions, you get the phenomenon we have observed where the same patterns of research are funded." Edwards is an advisor to the IDG program.

Margolis emphasized that although the NIH wants to spotlight proteins that could be druggable, this is a basic discovery project. "We don't know that any of these is going to turn into targets, but we want to lay the groundwork so that somebody down the road could take an interesting observation and advance it further," he said. "This is a precompetitive space."

$\mathrm{He}$ added that NIH funding for these projects is particularly critical as pharma cuts back internal discovery efforts. "It looks like the pharmaceutical industry is pulling back from high-risk basic proteome analysis coupled with pharmacology," he said.

In addition to the funded projects, IDG is working with another Common Fund project, the Knockout Mouse Phenotyping program, to prioritize the generation of knockout mice for the druggable protein classes.

According to Edwards, although $\$ 5.8$ million is a relatively small amount for an NIH program, it is a significant first step because almost no agency is willing to commit funds to an exploratory project like this in the current funding environment. "When funders make decisions like this, they do it knowing full well there will be reactions from their constituents. It's quite a sensitive time, and while intellectually we all understand there is a need to study these unstudied proteins, in practice it is still hard because the money needs to be taken from somewhere else. I applaud the NIH for even its small steps in that direction.”

Cain, C. SciBX 7(34); doi:10.1038/scibx.2014.1002

Published online Sept. 4, 2014

\section{REFERENCES}

1. Knapp, S. et al. Nat. Chem. Biol. 9, 3-6 (2013)

\section{COMPANIES AND INSTITUTIONS MENTIONED}

National Institute of Diabetes and Digestive and Kidney

Diseases, Bethesda, Md.

National Institutes of Health, Bethesda, Md.

Structural Genomics Consortium, Oxford, U.K. 